\title{
Cytotoxic Potential of Arthrospira platensis Extract on Cervical Cancer Cells Line Hela: Study on Antiproliferative, Cell Cycle, Apoptosis Induction and Anti Metastasis
}

\author{
Laela Hayu Nurani, Nurkhasanah Mahfudh*, Ibnu Gholib Gandjar and Intan Rahayu
}

Faculty of Pharmacy, Universitas Ahmad Dahlan, Kampus 3, Jl. Prof. DR. Soepomo Sh, Yogyakarta, 55164 Indonesia

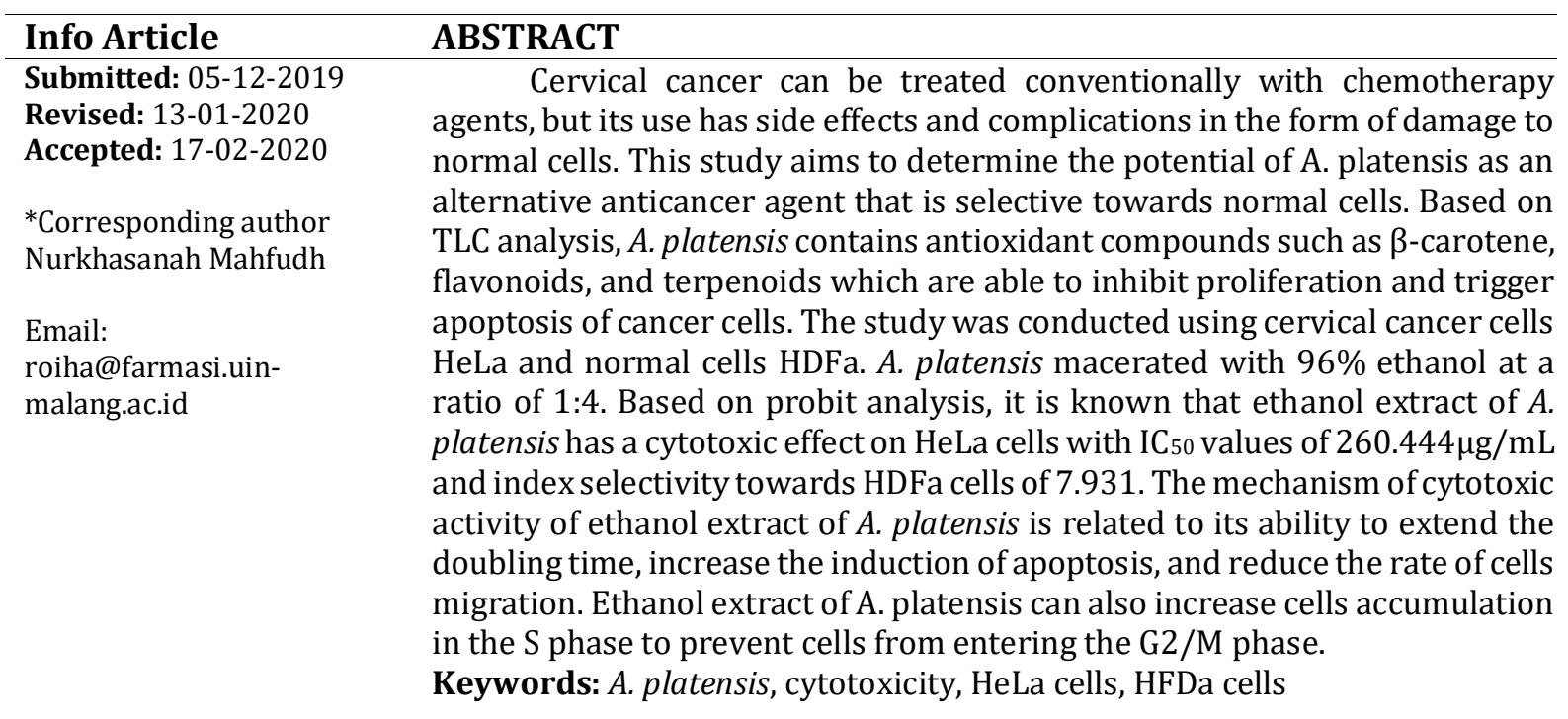

\section{INTRODUCTION}

Cervical cancer can occur due to an infection by the Human Papilloma Virus (HPV) that cause mutations in the p53 gene and increased expression of the protein $\mathrm{Bcl}-2$ which resulted in an imbalance between proliferation and cell (Sari and Syahrul, 2014). One of the methods chosen to treat cervical cancer is by giving chemotherapy agents. However, chemotherapy agents have side effects and complications in the form of normal cell damage (Huang et al., 2018). Therefore, it is necessary to develop alternative anticancer agents which are selective towards cancer cells without affecting normal cells.

Previous research showed that $A$. platensis contains antioxidant compounds such as $\beta$ carotene, flavonoids, terpenoids, and saponin compounds (Muszynska et al., 2018). Antioxidant compounds are able to regulate antiapoptotic proteins in the mitochondria to increase the induction of apoptosis (Muszynska et al., 2018). In addition, antioxidant compounds also have the ability to repair DNA or RNA damage in normal cells which will trigger the activation of the p53 gene so that there is a cessation of cell cycle and inhibition of cancer cell proliferation (Nugraheni et al., 2013). Based on this, it is necessary to investigate A. platensis cytotoxicity against HeLa cervical cancer cells. HeLa cells are cervical cell cultures infected with HPV and express 2 oncogens, namely E6 and E7 so that they can multiply in culture media and have cancer properties (Lucey et al., 2009). The selectivity test for A. platensis is done using Human Dermal Fibroblast Adult (HDFa) cells, HDFa cells are primary cell cultures that can present responses to stress and other biological approaches that approach in vivo situations in humans (Özen et al., 2005). The cytotoxic mechanism of an anticancer agent is related to its ability to inhibit proliferation and induce apoptosis (Moningka, 2019). Therefore, an antiproliferation test was performed to determine the doubling time value to show the ability of $A$. platensis to inhibit HeLa cells proliferation, flow cytometry analysis to observe inhibition patterns in the cell cycle and the magnitude of apoptosis induction in HeLa cells due to A. platensis treatment, and cell migration inhibition test with wound healing assay to determine the effect of $A$. platensis on the process of metastatic HeLa cancer cells (Lee et al., 2014). 


\section{MATERIAL AND METHODS}

\section{Plant material and cell culture}

A. platensis obtained from the Serba Alami Store, Bantul, Yogyakarta in November 2018. The sample has been identified at the Faculty of Biology, Gadjah Mada University. The test subjects used were HeLa cells and HDFa cells which are collections from the in Vitro Cell Culture Laboratory at Yogyakarta Muhammadiyah University. HeLa and HDFa cells were maintained in the RPMI medium with supplemented with FBS and cultured under $5 \% \mathrm{CO}_{2}$ and $37^{\circ} \mathrm{C}$.

\section{Extraction and phytochemical screening}

A total of $100.103 \mathrm{~g}$ of $A$. platensis powder was macerated with $400 \mathrm{~mL}$ of $96 \%$ ethanol. Phytochemical Screening was done by Thin Layer Chromatography (TLC) method, using silica gel GF254 as stationary phase, and various mobile phases such as hexan:acetone (4:1) which are used to analyze $\beta$-carotene, toluene:ethyl acetate (93:7) which are used to analyze terpenoids, chloroform:methanol:water (64:50:1) for analyzing saponins, and hexan:ethyl acetate:formic acid (6:4:0.2) for analyzing flavonoids. All of chemicals used were analytical grade from Merck.

\section{Cytotoxicity tests on HeLa cells and HFDa cells}

Cells were distributed into wells in 96 well plates (each well containing $2 \times 10^{4}$ cells) and incubated at $37^{\circ} \mathrm{C}, 5 \% \mathrm{CO}_{2}$ overnight. Following incubation, the various concentration series (62.5$2000 \mu \mathrm{g} / \mathrm{mL}$ ) of A.platensis extract were added into each well and incubated for $24 \mathrm{~h}$. At the end of the incubation, $10 \mu \mathrm{L} 0.5 \%$ MTT in PBS was added to each well. The reaction was stopped by adding $10 \%$ SDS, and stand for $4 \mathrm{~h}$ before measuring the intensity. The intensity of the purple color formed was measured by the ELISA reader at a wavelength of 595nm (Sulistyani and Nurkhasanah, 2017).

\section{Doubling time test}

Cells were starved in culture media containing $0.5 \%$ FBS for $24 \mathrm{~h}$ in 96 well plate (each well containing $2 \times 10^{4}$ cells), then cells were incubated with ethanol extract of $A$. platensis with a concentrations $156.575 \mu \mathrm{g} / \mathrm{mL}$ and $78.288 \mu \mathrm{g} / \mathrm{mL}$. Cell population in each series of experiments was calculated at 24,48 , and $72 \mathrm{~h}$ incubation time with ELISA readers at a wavelength of $595 \mathrm{~nm}$, then a curve of cell number vs. incubation time ware made. The doubling time is calculated from the slop after a straight line is drawn on the curve (CCRC, 2017).

\section{Cell cycle analysis by flow cytometry}

Cells were distributed into 6 well plates (each containing $5 \times 10^{5}$ cells) and incubated with test samples at a concentrations of $156.575 \mu \mathrm{g} / \mathrm{mL}$ and $78.288 \mu \mathrm{g} / \mathrm{mL}$ for $24 \mathrm{~h}$. At the end of the treatment, the media in each well was put in a different conical. Cells were washed with $500 \mu \mathrm{L}$ PBS and added with $200 \mu \mathrm{L}$ trypsin-EDTA $0.25 \%$ to the cell, then incubated for $3 \mathrm{~min}$ to detach the cells and then added with $500 \mu \mathrm{L}$ of media. Cell suspension was then centrifuged at $600 \mathrm{rpm}$ for 5 minutes. The precipitate was fixed with cold $70 \%$ ethanol, and let it for $30 \mathrm{~min}$ at room temperature and followed by centrifugation at $2000 \mathrm{rpm}$ for 3 minutes and washed with PBS. Following washing, $400 \mu \mathrm{L}$ PI reagent (propidium iodide) $1 \mathrm{mg} / \mathrm{mL}$ (Sigma), 10mg/mL RNAse (Sigma) and 0.1\% (v/v) Triton-X 100 (Sigma) were added. Cells were resuspended and incubated for $5 \mathrm{~min}$ in a dark room, then read with a flow cytometer with a light beam of $488 \mathrm{~nm}$ and a medium speed of 500cells /s (Mahfudh and Pihie, 2008).

\section{Annexin $\mathrm{V}$ apoptosis detection assay}

For apoptotic observations, Following the treatment, incubation and washing, the cells was then resuspended with $100 \mu \mathrm{L}$ binding buffer, $2 \mu \mathrm{L}$ Anexin-V and $2 \mu \mathrm{L} \mathrm{PI}$, then incubated in a dark room for 10 minutes. Cell suspension is read with a flow cytometer with a light beam of $488 \mathrm{~nm}$ and a medium speed of 500cells/s (Mahfudh and Pihie, 2008).

\section{Scratch wound healing assay}

Cells were starved in culture media containing $0.5 \%$ FBS for $24 \mathrm{~h}$ into 6 well plates (each containing $7.5 \times 10^{4}$ cells). Then a scratch was made on the surface of the well using sterile yellow tips and given a test sample with a concentration of $156.575 \mu \mathrm{g} / \mathrm{mL}$ and $78.288 \mu \mathrm{g} / \mathrm{mL}$. Cell condition was observed and documented after incubation of $0,18,24$ and $48 \mathrm{~h}$. Then the stroke distance between cell control and treatment was compared using ImageJ Software (Jonkman et al, 2014).

\section{Data analysis}

Data obtained from ELISA in the form of absorbance is converted as a percentage of cell death. After the percentage (\%) of cell death was obtained, it can be calculated that the extract concentration can inhibit the growth of $50 \%$ of the cell population ( $\mathrm{IC}_{50}$ value) by probit analysis according to SPSS version 20. 
Table 1. The result of phytochemical screening of ethanol extract of $A$. platensis by using TLC method

\begin{tabular}{|c|c|c|c|c|c|c|c|c|c|c|}
\hline \multirow{2}{*}{\multicolumn{2}{|c|}{ Testing }} & \multirow{2}{*}{$\begin{array}{l}\text { Detector } \\
\text { reagents }\end{array}$} & \multirow{2}{*}{ Rf } & \multicolumn{3}{|c|}{$\begin{array}{l}\text { Spotting without } \\
\text { detector reagent }\end{array}$} & \multicolumn{3}{|c|}{$\begin{array}{c}\text { Spotting with detector } \\
\text { reagents }\end{array}$} & \multirow{2}{*}{ Conclusion } \\
\hline & & & & $\begin{array}{l}\text { Visible } \\
\text { rays }\end{array}$ & $\begin{array}{l}\text { UV rays } \\
254 \mathrm{~nm} \\
\end{array}$ & $\begin{array}{l}\text { UV rays } \\
366 \mathrm{~nm}\end{array}$ & $\begin{array}{l}\text { Visible } \\
\text { rays }\end{array}$ & $\begin{array}{l}\text { UV rays } \\
254 \mathrm{~nm}\end{array}$ & $\begin{array}{l}\text { UV rays } \\
366 \mathrm{~nm}\end{array}$ & \\
\hline \multirow[t]{2}{*}{ B-carotene } & $\begin{array}{l}\text { Ethanol extract } \\
\text { of } A \text { platensis }\end{array}$ & - & $\begin{array}{l}0.16 \\
0.19 \\
0.31 \\
0.44\end{array}$ & $\begin{array}{l}\text { Green- } \\
\text { yellow }\end{array}$ & Green & Purple & - & - & - & \multirow[t]{2}{*}{ positive } \\
\hline & $\begin{array}{l}\text { B-carotene } \\
\text { standard }\end{array}$ & - & 0.93 & $\begin{array}{l}\text { Green- } \\
\text { yellow }\end{array}$ & Green & Purple & - & - & - & \\
\hline \multirow[t]{2}{*}{ Terpenoids } & $\begin{array}{l}\text { Ethanol extract } \\
\text { of } A \text { platensis }\end{array}$ & \multirow{2}{*}{$\begin{array}{l}\text { Anisaldehyde- } \\
\text { sulfuric acid }\end{array}$} & $\begin{array}{l}0.13 \\
0.38 \\
0.81\end{array}$ & - & - & - & $\begin{array}{l}\text { Purplish } \\
\quad \text { red }\end{array}$ & $\begin{array}{l}\text { Purplish } \\
\text { red }\end{array}$ & Purplish red & \multirow[t]{2}{*}{ positive } \\
\hline & $\begin{array}{l}\text { Eugenol } \\
\text { standard }\end{array}$ & & 0.56 & - & - & - & $\begin{array}{l}\text { Purplish } \\
\text { red }\end{array}$ & $\begin{array}{l}\text { Purplish } \\
\text { red }\end{array}$ & Purplish red & \\
\hline Saponin & $\begin{array}{c}\text { Ethanol extract } \\
\text { of } A \text { platensis } \\
\text { Sapogenin } \\
\text { standard }\end{array}$ & $\begin{array}{l}\text { Liebermann- } \\
\text { Burchard }\end{array}$ & 0.6 & brown & brown & brown & brown & brown & brown & positive \\
\hline \multirow[t]{2}{*}{ Falvonoids } & $\begin{array}{l}\text { Ethanol extract } \\
\text { of } A \text { platensis }\end{array}$ & \multirow{2}{*}{$\begin{array}{l}\text { Citric-boric } \\
\text { acid }\end{array}$} & 0.51 & $\begin{array}{l}\text { Green- } \\
\text { yellow }\end{array}$ & $\begin{array}{l}\text { Green- } \\
\text { yellow }\end{array}$ & $\begin{array}{l}\text { Green- } \\
\text { yellow }\end{array}$ & $\begin{array}{l}\text { Green- } \\
\text { yellow }\end{array}$ & $\begin{array}{l}\text { Green- } \\
\text { yellow }\end{array}$ & $\begin{array}{l}\text { Yellow } \\
\text { fluorescence }\end{array}$ & \multirow{2}{*}{ positive } \\
\hline & $\begin{array}{l}\text { Quercetin } \\
\text { standard }\end{array}$ & & 0.38 & $\begin{array}{l}\text { Green- } \\
\text { yellow }\end{array}$ & $\begin{array}{l}\text { Green- } \\
\text { yellow }\end{array}$ & $\begin{array}{l}\text { Green- } \\
\text { yellow }\end{array}$ & $\begin{array}{l}\text { Green- } \\
\text { yellow }\end{array}$ & $\begin{array}{l}\text { Green- } \\
\text { yellow }\end{array}$ & $\begin{array}{c}\text { Yellow } \\
\text { fluorescence }\end{array}$ & \\
\hline
\end{tabular}

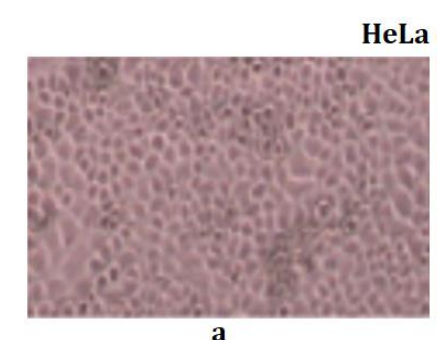

a

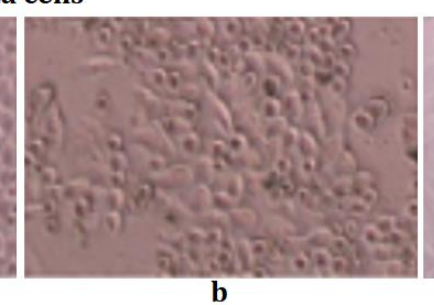

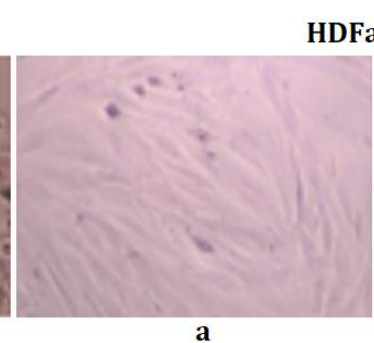

HDFa cells

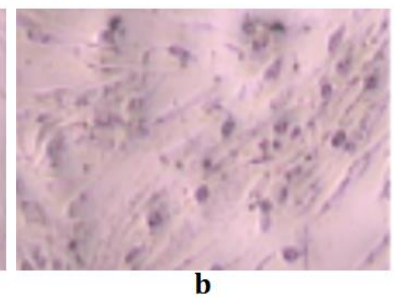

Figure 1. Changes in the morphology of HeLa cells and HDFa cells after 24 hours incubation in the control group (a) as well as those treated with ethanol extract of $A$. platensis (b)

Selectivity is calculated by comparing the $\mathrm{IC}_{50}$ value of HDFa cells with $\mathrm{IC}_{50}$ cells of HeLa cells. The data of doubling time, \% apoptosis, and \% cell migration were analyzed by One Way Anova followed by Post Hoc Tukey's Test at $\mathrm{p}<0.05$. The cell cycle was analyzed by comparing the largest cell accumulation between treatment and control.

\section{RESULT AND DISCUSSION Phytochemical screening}

The maceration process produced 2.235 gram of ethanol extract of $A$. platensis with an extraction rate of $2.233 \%$. Based on TLC results, ethanol extract of $A$. platensis contains $\beta$-carotene, terpenoids, and flavonoid compounds (Table I). The previous research showed the potency of these compound to increase apoptosis and inhibit proliferation of cancer cells (Wati et al., 2016).
Cytotoxicity tests on HeLa cells and HFDa cells

The treatment of ethanol extract of $A$. platensis causes morphological changes in HeLa cells and HDFa cells. Some of HeLa cells were shrink and detach to each other (contact inhibition) and decrease in number, as well as HDFa cells (Figure 1). After observing cell morphology, cells are given an MTT solution. The more formazan crystals formed, the absorbance measured in ELISA Reader is higher and more cells are still alive (Suzery and Cahyono, 2014). The percentage of deaths due to ethanol extract of $\mathrm{A}$. platensis in HeLa cells increases when the concentration increases. The same thing happened with HDFa cells, an increase in the concentration of ethanol extract A. platensis also resulted in an increase in the percentage of cell death. However, the dose needed to cause hindrance to HDFa cell viability is higher than the 
dose needed to cause hindrance to viability in HeLa cells (Figure 2).

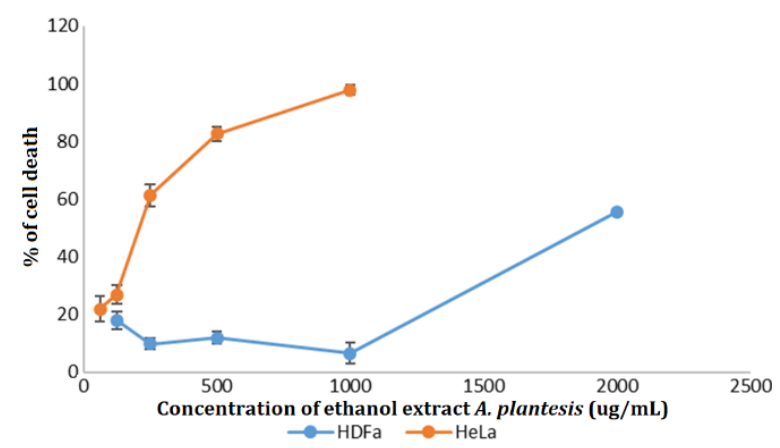

Figure 2. The cytotoxic effect of the ethanol extract of $A$. platensis on HeLa cells and HDFa cells

The extract has a strong cytotoxic activity if it has $\mathrm{IC}_{50}<100 \mu \mathrm{g} / \mathrm{mL}$ or moderate if $100 \mu \mathrm{g} / \mathrm{mL}$ $<\mathrm{IC}_{50}<1000 \mu \mathrm{g} / \mathrm{mL}$ against cancer cells, while the extract is toxic to normal cells if it has an $\mathrm{IC}_{50}$ value $<1000 \mu \mathrm{g} / \mathrm{mL}$ and said not toxic if the $\mathrm{IC}_{50}$ value $>1000 \mu \mathrm{g} / \mathrm{mL}$ (Benedetti et al., 2010). The present study found that, the $\mathrm{IC}_{50}$ values of A.platensis extract against Hela cells and HDFa cells were $260.444 \mu \mathrm{g} / \mathrm{mL}$ and $2065.662 \mathrm{ug} / \mathrm{mL}$ respectively. Therefore, it can be concluded that the ethanol extract of A. platensis has moderate cytotoxic activity against HeLa cells and is not toxic to normal HDFa cells. The cytotoxic activity of ethanol extract of $A$. platensis could be caused by its chemical content including $\beta$-carotene, terpenoid, and flavonoid. The previous studies suggested the potency of compounds as cytotoxic agent (Wati et al., 2016). The study of cytotoxicity mechanism of the extract was carried out in concentration under $\mathrm{IC}_{50}$ including $156.575 \mathrm{ug} / \mathrm{mL}$ and $78.288 \mathrm{ug} / \mathrm{mL}$ to allow the cells grow and could be observed.

\section{The selectivity of ethanol extract of $A$. platensis} Ethanol extract of $A$. platensis has a selectivity index (SI) of 7.9313, so it can be concluded that ethanol extract A. platensis is selective against HeLa cancer cells. The mechanism of ethanol extract of $A$. platensis to distinguish cancer cells from normal cells is based on the cells need for Adenosine Triphosphate (ATP). Because cancer cells move, grow and multiply faster and are more active than normal cells, cancer cells need more ATP energy. The previous studies showed the potency of flavonoids as anticancer agent (Abotaleb et al., 2019) through inducing apoptosis. Another mechanism of flavonoid in inhibiting of cancer progression is through its ability to target molecular pathways involved in glucose metabolism and mitochondrial function (ReyesFariaz and Carrasco-Pozo, 2019).

\section{Doubling time test}

Based on Post Hoc Tukey's Test stated that ethanol extract of $A$. platensis caused a significant increasing of HeLa cells doubling time compared to the control group (Figure 3). The higher the concentration of the extract given, the longer the doubling time obtained (Table II). This result showed that treatment of A.platensis extract could inhibit the cancer cells proliferation. In the control group, it was found the doubling time is shorter. It showed that without treatment, Hela cells proliferate faster. Inhibition of proliferation on HeLa cells due to the administration of ethanol extract of $A$. platensis occurs through the mechanism of inhibiting the action of oxidation enzymes that play a role in the production of ATP by flavonoids so that the energy used for cell division is less available (Sahid et al., 2013). After that, $\beta$-carotene can increase p53 which gives effect to cell cycle termination (Nugraheni et al., 2013). When the cell cycle is stopped, it is possible for cells to make DNA repairs, which are maximized by terpenoids. Terpenoids have the ability to inhibit cancer cell proliferation by triggering DNA repair mechanisms and inhibiting DNA fragmentation (Thoppil and Bishayee, 2011).

\section{Cell cycle analysis by flow cytometry}

Ethanol extract of $A$. platensis can cause accumulation of HeLa cells in the $S$ phase which can cause the inhibition of HeLa cells to enter the G2/M phase (Figure 4).

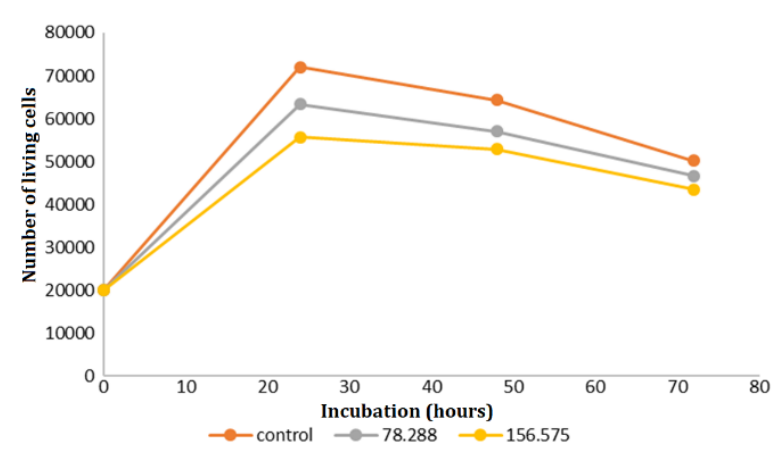

Figure 3. Effect of ethanol extract of $A$. platensis on the number of living cells at various incubation times 

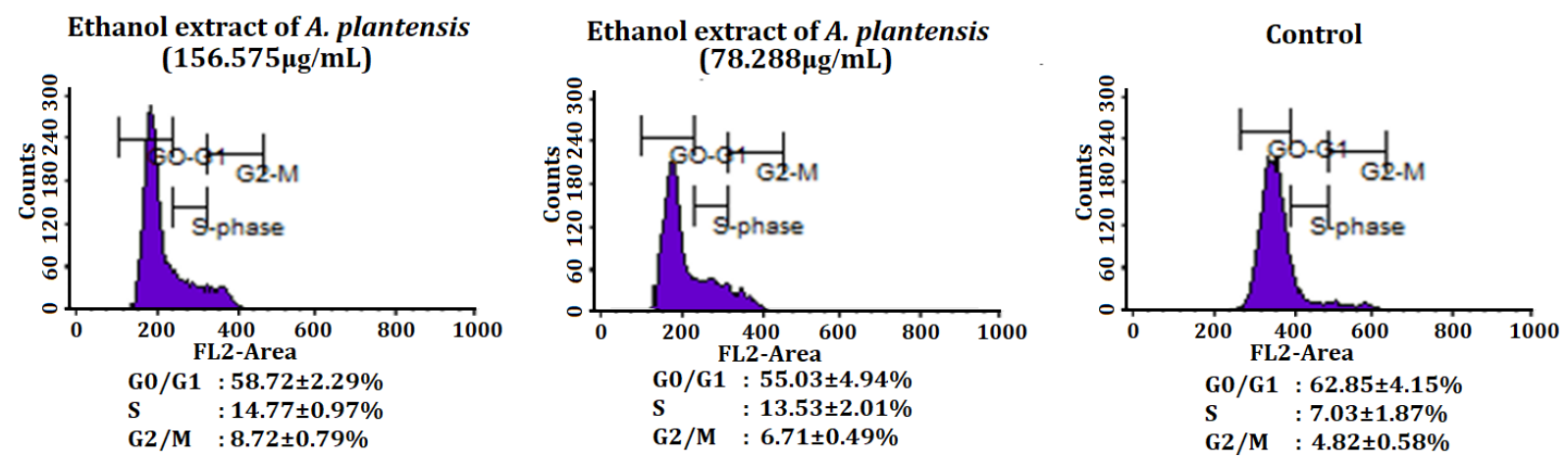

Figure 4. Results of HeLa cell cycle profile analysis treated with ethanol extract of A. platensis using the Flow cytometry method
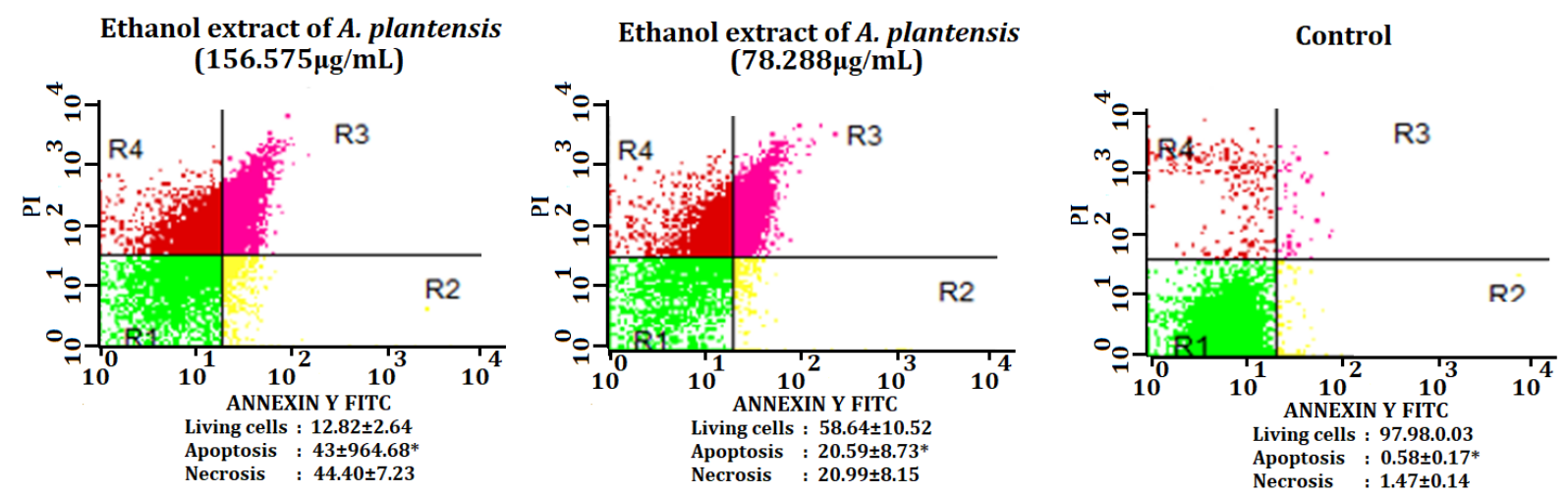

Figure 5. Results of HeLa cell population treated with ethanol extract of A. platensis using the Flow cytometry method

Note: (a)p $<0.05$ vs concentration of $156.575 \mu \mathrm{g} / \mathrm{mL}$; (b)p $<0.05$ concentration of $\left.72.288 \mu \mathrm{g} / \mathrm{mL} ;{ }^{*}\right) \mathrm{p}<0.05$ vs control

In the G2/M phase the cells are ready to divide, in this phase the process of DNA replication and the biosynthesis of proteins and RNA needed for cell division have been perfected. Barriers to cell cycles in the G2/M phase produce regulatory errors that cause delayed or disrupted cell division (Lacroix and Maddox, 2014).

Inhibition of the cell cycle in HeLa cells is caused by the content of $\beta$-carotene, flavonoid, and terpenoids compounds contained in the ethanol extract of $A$. platensis. In general, $\beta$-carotene compounds have the ability to increase p53 which is able to recognize cells with damaged DNA and stimulate transcription of genes such as p21 or Bax so that the cell cycle stops and DNA has the opportunity to repair itself before entering the next division stage (Nugraheni et al., 2013). While the mechanism of action of flavonoid compounds is to prevent the formation of active CDK-Cyclin complexes thereby suppressing Maturation Promoting Factor (MPF), this results in disruption of checkpoints in the S and G2/M phases so that cells cannot complete their cell cycle (Wati et al., 2016). The terpenoid compounds have a mechanism of action in blocking the cell cycle in the G2/M phase by stabilizing the spindle threads in the mitotic phase, thus causing the process of mitosis to be inhibited (Setiawati et al., 2007).

\section{Annexin $\mathrm{V}$ apoptosis detection assay}

Based on flowytometry analysis, ethanol extract of A. platensis has the ability to induce cell death through the necrosis pathway, this is reflected in the number of cells undergoing necrosis more than the number of cells undergoing apoptosis in both treatment groups (Figure 5). However, it should be noted that in both treatment groups the range of cells undergoing necrosis and apoptosis is not too far away, so it is necessary to optimize the concentration ethanol extract of $A$. platensis so that the cell population undergoing apoptosis is more optimal. Necrosis can also be caused by an incubation period that is too long (24h) so that the apoptotic phase has passed. 


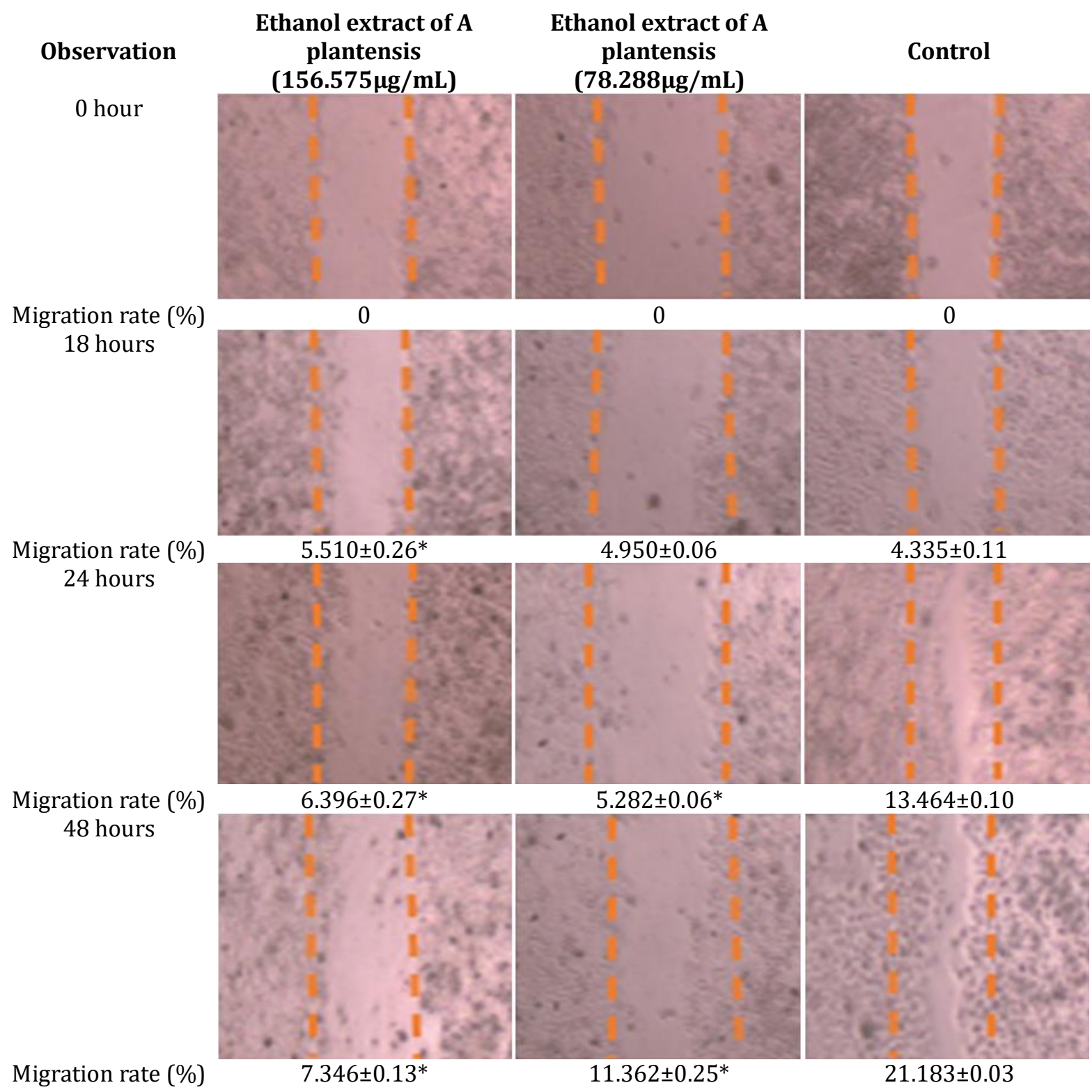

Figure 6. The effect of ethanol extract of $A$. platensis on the migration ability of HeLa cells Note: (a)p<0.05 vs concentration of $156.575 \mu \mathrm{g} / \mathrm{mL}$; (b)p $<0.05$ concentration of $72.288 \mu \mathrm{g} / \mathrm{mL}$; (*)p $<0.05 \mathrm{vs}$ control

Tukey's Post Hoc test stated that ethanol extract of A. platensis caused a significant increase in apoptosis on HeLa cells compared to the control group.

Apoptosis induction in HeLa cells is caused by the content of $\beta$-carotene, flavonoid, and terpenoid compounds contained in ethanol extract of A. platensis. Flavonoid compounds have the ability to increase the expression of p53. The p53 gene will stimulate the mitochondria to release cytochrome $\mathrm{C}$ to the cytosol and activate the exclusionary caspase so that it can cause apoptotic cell death (Setiawan et al., 2017). The terpenoid compounds will make the bond between the topoisomerase enzyme and the DNA of the cancer cell held longer so that it results in fragmentation or damage to the cancer cell DNA. DNA damage can increase the expression of proapoptotic proteins such as Bax and Bak and decrease the expression of antiapoptotic proteins namely Bcl-2 and Bcl-XL (Susianti, 2016). The mechanism of action is then strengthened by $\beta$-carotene compounds which 
have the ability to reduce the expression of Bcl-2 and induce the release of cytochrome $c$ from mitochondria in HeLa cells which results in increased induction of apoptosis (Palozza, 2005).

\section{Scratch wound healing assay}

The scratch wound healing assay was carried out to observed the effect of extract in inhibiting migration of the cancerous cells. The capability of extract to inhibit the cell migration could inhibit the progression of cells, which is the important part of cancerous cells to spread and metastatic.

Based on the Post Hoc Tukey's test stated that ethanol extract of $A$. platensis caused significant decreasing the migration rate of HeLa cells when compared to the control group (Figure 6). Decreased rate of cell migration in HeLa cells is caused by suppression of MMP-9 expression due to inhibition of $N F-\kappa B$ activity by antioxidant compounds such as $\beta$-carotene, flavonoid, and terpenoid compounds, which are contained in the ethanol extract of $A$. platensis (Sung et al., 2012). Decreased rate of cell migration can illustrate a decrease in the ability of cancer cells to separate from primary tumors into more distant tissues and colonize other organs to form secondary tumors (Zhang et al., 2007). Barriers to cell spreading signify a delay in the metastatic process from cancer (Jiang et al., 2015).

\section{CONCLUSION}

Ethanol extract of $A$. platensis has a cytotoxic effect on HeLa cells with an IC50 value of 260.444 $\mu \mathrm{g} / \mathrm{mL}$ and selective against normal HDFa with SI 7.9313. These cytotoxic properties are related to delays in doubling time, triggers apoptosis, inhibition of the cell cycle in the G2/M phase, and inhibition of cell migration. Cytotoxic effects are caused by $\beta$-carotene, terpenoid, and flavonoid compounds contained in the ethanol extract of $A$. platensis.

\section{ACKNOWLEDGEMENT}

The authors' expression of gratitude is addressed to LPPM of Ahmad Dahlan University for funding this research.

\section{REFERENCES}

Abotaleb M., Samuel SM., Varghese E., Varghese,S., Kubatka P., et al., 2019. Flavonoids in cancer and apoptosis. Cancers, 11(1), 1-39.

Benedetti S., Benvenuti F., Scoglio S., Canestrari, F., 2010. Oxygen Radical Absorbance Capacity of Phycocyanin and Phycocyanobilin from The Food Supplement Aphanizomenon FlosAquae. J Med Food. 13(1): 223-227.

Huang MY., Zhang LL., Ding J., Lu JJ., 2018. Anticancer Drug Discovery from Chinese Medicinal Herbs. Chinese Medicine.13(1): 35.

Jiang WG., Sanders AJ., Katoh M., Ungefroren H., Gieseler F., et al., 2015. Tissue invasion and metastasis: Molecular, biological and clinical perspectives. Seminars in Cancer Biology. Vol. 35: S244-S275.

Lacroix B., Maddox AS., 2012. Cytokinesis, Ploidy and Aneuploidy. The J Pathology. 226(2): 338-351

Lee JW., Lee J., Moon EY., 2014, Hela Human Cervical Cancer Cell Migration Is Inhibited by Treatment with dibutyryl-cAMP. Anticancer Research. 34(7): 3447-3455.

Lucey BP., Nelson-Rees WA., Hutchins GM., 2009. Henrietta Lacks, Hela Cells, And Cell Culture Contamination. Archives of Pathology and Laboratory Medicine.133(9): 1463-1467.

Mahfudh N., Pihie AHL. 2008, Eurycomanone induces apoptosis through the up-regulation of p53 in human cervical carcinoma cells, $J$ Can Mol, 4(4): 109-115

Moningka ME., 2019, Development of Cancer Therapy Related to Terpineol, P53 and Caspase 3 Compounds 3. Jurnal e-Biomedik. 7(1): 37-43.

Muszynska B., Lazur J., Krakowska, Jekot B., Szewczyk A., et al., 2018. Release of Bioactive Substances from Formulations Containing Arthrospira Platensis (Spirulina Platensis). Acta Pol Pharm75(5): 1187-1199.

Nugraheni M., Santoso U., Wuryastuti, H., 2013. Potential of Black Potato in Reducing Oxidative Stress and Inhibiting the Proliferation of Breast Cancer Cells Mcf-7.J Food Tech and Industry. 24(2): 138.

Özen J., Atay A., Topçu FT., Ural AU., Dalkiz M., Tunca YM., 2005, Analysis of The Cytotoxicity Four Dentin Bonding Agents On Gingival Fibroblasts. Turk J Med Scie. 35(6): 395-399.

Reyes-FM., Carrasco-PC. (2019). The anti-cancer effect of quercetin: Molecular implications in cancer metabolism. Int J Mol Scie, 20(13), 119

Sari AP., Syahrul F., 2014. Factors Related to HPV Vaccine Practice Among Adult Women. Jurnal Berkala Epidemiologi. 2(3): 321-330.

Setiawati, A., Susidarti, R. A., dan Meiyanto, E., 2011, Increasing Cytotoxic Effect of Doxorubicin 
by Hesperidin On T47D Cancer Cell. Bionatura. 13(2): 82-95.

Sulistyani, N., Nurkhasanah, 2017, The cytotoxic effect of Elephantopus scaber Linn extract against breast cancer (T47D) cells, IOP Conf. Series: Materials Science and Engineering 259: 1-6.

Sung HJ., Kim Y., Kang H., Sull JW., Kim YS., Jang SW., Ko J., 2012. Inhibitory Effect of Trolox On the Migration and Invasion of Human Lung and Cervical Cancer Cells. Int J Mol Medicine. 29(2): 245-251.

Susianti S., 2016. Thymoquinone Effect to Apoptosis on Cervical Cancer Cell. Jurnal Kedokteran Universitas Lampung.1(2): 267271.

Sutejo IR., Putri H., Meiyanto E., 2016. Ethanolic Leaves Extract of Awar-awar (Ficus Septica) as Selective Chemopreventive Agent on
Various Cancer Cells. NurseLine Journal. 1(2): 190-197.

Suzery M., Cahyono B., 2014. Evaluation of Cytotoxicity Effect of Hyptis pectinata Poit Extracts Using BSLT and MTT Methods. Jurnal Sains dan Matematika. 22(3): 84-88

Thoppil RJ., Bishayee A., 2011. Terpenoids as Potential Chemopreventive and Therapeutic Agents in Liver Cancer. World Journal of Hepatology. 3(9): 228.

Wati EM., Puspaningtyas AR., Pangaribowo DA., 2016, Cytotoxicity and Proliferation Studies of 1-(4-nitrobenzoyloxy- methyl)-5fluorouracil) on Breast Cancer Cells MCF-7. Pustaka Kesehatan. 4(3): 484-488.

Zhang L., Wang T., Wen X., Wei Y., Peng X., et al., 2007. Effect of Matrine On Hela Cell Adhesion and Migration. EurJ Pharm. 563(13): 69-76. 